\title{
Environmental and economic potential of rice husk use in An Giang province, Vietnam
}

\author{
Tiềm năng kinh tế và môi trương của việc sủ dụng trấu tại tỉnh An Giang, Việt \\ Nam \\ Research article
}

Pham, Thi Mai Thao*

Environment Faculty, Ha Noi University of Natural Resources and Environment, 41A Phu Dien Street, Cau Dien Ward, Bac Tu Liem District, Hanoi, Vietnam

\begin{abstract}
To evaluate $\mathrm{CO}_{2}$ emission mitigation potential and cost effectiveness of rice husk utilization, Life Cycle Analysis was conducted for 9 scenarios. The results showed that, gasification is the most efficient $\mathrm{CO}_{2}$ mitigation. From cost analysis, the cost mitigation can be achieved by replacing the current fossil fuels in cooking scenarios. Among the power generation scenarios, it was found that $30 \mathrm{MW}$ combustion and 5MW gasification power generations were the most economically-efficient scenarios. The briquette combustion power generation appeared less cost-competitive than direct combustion, whilst the large-scale gasification scenarios and the pyrolysis scenarios give the increase in cost from the baseline. From the viewpoints of both $\mathrm{CO}_{2}$ and cost, it was indicated that the win-win scenarios can be the rice husk use for cooking, for large-scale combustion power generation, and for small-scale gasification.
\end{abstract}

Để đánh giá tiềm năng giảm thiểu phát thải $\mathrm{CO}_{2}$ và hiệu quả chi phí của việc sủ dụng trấu, phuoong pháp đánh giá vòng đời sản phẩm đã đurợc thực hiện cho 9 kịch bản. Kết quả cho thẩy, khí hóa trấu để sản xuất điện có tiềm năng giảm phát sinh khi $\mathrm{CO}_{2}$ nhiều nhất. Kết quả phân tích chi phí cho thấy việc giảm thiểu chi phí có thể đạt được khi thay thế sử dụng nhiên liệu hóa thạch trong kịch bản dùng trấu cho nấu ăn. Giữa các kịch bản về sản xuất điện, hiệu quả kinh tế cao nhất trong truòng hơp đốt trực tiếp trấu để sản xuất điện ở quy mô công xuất lớn (30MW) và khí hóa ở quy mô trung bình $(5 \mathrm{MW})$. Truờng hợp dùng củi trấu không mang lại hiệu quả kinh tế so với dùng trục tiếp trấu để phát điện. Hai truờng hợp dùng trấu để sản xuất dầu sinh học và khí hóa gas công suất lớn $(30 M W)$ cho thấy chi phí tăng cao so với điều kiện biên. Kịch bản cho kết quả khả thi về hiệu quả kinh tế và giảm phát thải $\mathrm{CO}_{2}$ là dùng trấu để nấu ăn, đốt trục tiếp để phát điện công suất lớn và khi hóa công suất trung bình.

Keywords: cooking, combustion, gasification, pyrolysis, life cycle assessment

\section{Introduction}

Rice husk is one of the most widely available agricultural wastes in many rice producing countries. In Vietnam, rice husk has been utilized for various local needs such as organic fertilizer, cooking fuel, and building material, however, the traditional use is decreasing. In the Mekong River Delta, there are many rice mills distributing and generating husks are not appropriately treated. The estimation conducted by the local authority shows that 3.6 million tons of rice husks are annually produced, some of which are dumped into the dense canal and river systems [1]. The discharged rice husks decrease the dissolved oxygen seriously by covering the water surfaces. In addition, it is seen that mill owners burn the excess rice husks in the open air. This causes not only respiratory diseases but also severe fire accidents. However, there have not been shown any policies and supports by the Vietnamese government to treat or use them so far.

Rice husks are defined as renewable energy resource. Converting rice husks into heat, stream, gases or liquid fuels would bring benefit to countries that have no conventional energy resources [2]. It is also a good chance to expand the energy resources as well as to reduce the environmental burden derived by the disposal of rice husks. In this study, the $\mathrm{CO}_{2}$ mitigation potential and economic effectiveness by rice husk utilization was evaluated by using Life Cycle 
Assessment to propose possible strategies for rice husk usage from the viewpoints of both $\mathrm{CO}_{2}$ and cost.

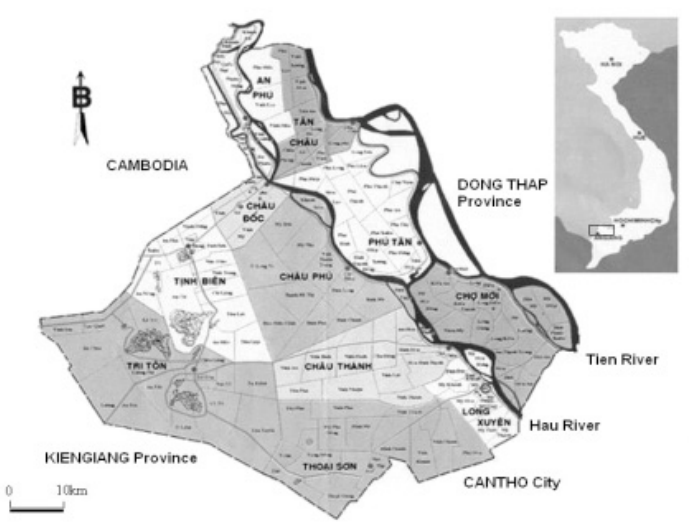

Figure 1. Map of An Giang province

\section{Methodology}

\subsection{Study area}

An Giang province (Fig. 1) situated in the Mekong River Delta region was selected as the study area, because it has the largest paddy area in Vietnam with 520,000 ha in use
[2] and, therefore, it can be a potential market place for rice husk energy production. There are more than 1,000 rice mills, of which more than 200 have larger capacities above $100 \mathrm{t} / \mathrm{d}$ [2]. The total quantity of rice husks in An Giang province for 2015 was estimated at 620,000 tons per year $(\mathrm{t} / \mathrm{y})$.

\subsection{Scenario setting}

Based on rice husk supply and current local demands, the following scenarios were set up (see Table 1). The total supply was fixed at $620,000 \mathrm{t} / \mathrm{y}$.

S0 is baseline scenario, in which current demands for cooking $(8.6 \%)$ and brick making $(25.8 \%)$ were maintained, and the excess $(65.6 \%)$ was considered treated by open burning. In S1, all excess rice husks are used for cooking to replace coal, LPG, and finally, fuel wood. In S2 and S3 scenarios, the excess rice husks $(65.6 \%)$ were assumed to be used for power generation through combustion (S2) or gasification (S3). S4 is scenario for bio-oil production by pyrolysis that current demand was maintained. In S1B, we were assumed to replace coal and LPG in rural areas with briquettes. In S2B, excess rice husks were allocated to briquette production and then used for power generation as with S2.

Table 1. Fuel allocation in each scenario (*: baseline)

\begin{tabular}{|c|c|c|c|c|c|c|c|c|}
\hline & {$\left[10^{3} t / y\right]$} & S0* & S1 & $\mathbf{S 2}$ & S3 & S4 & S1B & S2B \\
\hline \multirow{6}{*}{ Cooking } & RH & 53 & 460 & 53 & 53 & 53 & 53 & 53 \\
\hline & RHB & 0 & 0 & 0 & 0 & 0 & 388 & 0 \\
\hline & Coal & 5.2 & 0 & 5.2 & 5.2 & 5.2 & 0 & 5.2 \\
\hline & LPG (urban) & 22.6 & 22.6 & 22.6 & 22.6 & 22.6 & 22.6 & 22.6 \\
\hline & LPG (rural) & 34.0 & 12.5 & 34.0 & 34.0 & 34.0 & 0 & 34.0 \\
\hline & Fuel wood & 434 & 0 & 434 & 434 & 434 & 393 & 434 \\
\hline \multirow{3}{*}{ Brick making } & $\mathrm{RH}$ & 160 & 160 & 160 & 160 & 160 & 160 & 160 \\
\hline & RHB & 0 & 0 & 0 & 0 & 0 & 0 & 0 \\
\hline & Coal & 0 & 0 & 0 & 0 & 0 & 0 & 0 \\
\hline \multirow{2}{*}{$\begin{array}{l}\text { Power combus- } \\
\text { tion }\end{array}$} & RH & 0 & 0 & 407 & 0 & 0 & 0 & 0 \\
\hline & RHB & 0 & 0 & 0 & 0 & 0 & 0 & 388 \\
\hline Gasification & RH & 0 & 0 & 0 & 407 & 0 & 0 & 0 \\
\hline Pyrolysis & $\mathrm{RH}$ & 0 & 0 & 0 & 0 & 407 & 0 & 0 \\
\hline Open burning & RH & 407 & 0 & 0 & 0 & 0 & 0 & 0 \\
\hline
\end{tabular}

Note: $a: 5 M W ; b: 30 M W$, B: briquette

\subsection{Preparations for life cycle inventory anal- ysis}

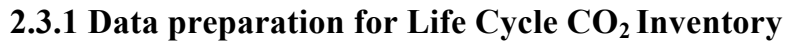 Analysis}

\section{(i) Direct combustion in cooking and brick making}

It is assumed that rice husks or briquettes can replace liquid petroleum gas (LPG), coal and fuel wood for household cooking and brick making. Emission from rice husk transportation for domestic use is negligible because people usually obtain the rice husks from neighborhood mills using bicycles or wood-boats. In the case of brick making, the furnace efficiency for each fuel - coal, fuel wood, rice husk, briquette - was not available, therefore, the requisite amount of fuel for the production of one brick was used instead: $0.3 \mathrm{~kg}$ of coal [3] or $0.18 \mathrm{~kg}$ of fuel wood [4]. The default $\mathrm{CO}_{2}$ emission factors for stationary combustion stated by the Intergovernmental Panel on Climate Change IPCC (2006) were summarized and used as shown in Table 2.

The total $\mathrm{CO}_{2}$ emission from household cooking and brick making in An Giang province was estimated with the equation as follows:

$$
E m_{\mathrm{CO}_{2}}=\Sigma\left(F_{i} \times E f_{i}\right)
$$

Where: $\mathrm{Em}_{\mathrm{CO} 2}: \mathrm{CO}_{2}$ emission $\left[\mathrm{tCO}_{2} / \mathrm{y}\right]$; Fi: consumption of fuel i $[\mathrm{t} / \mathrm{y}]$ (i: coal, LPG, fuel wood, rice husk, and briquette); Efi: $\mathrm{CO}_{2}$ emission factor of fuel i $\left[\mathrm{tCO}_{2} / \mathrm{t}\right.$ fuel] (with Global Warming Potential, $\mathrm{tCO}_{2} / \mathrm{t}$ GHG $\left(\mathrm{CH}_{4}: 21\right.$; $\mathrm{N}_{2} \mathrm{O}: 310$ - IPCC, 2006) 
Table 2. $\mathrm{CO}_{2}$ emission factors for stationary combustion in residential areas, [unit: $\mathrm{kgCO}_{2} / \mathrm{kg}$ fuel], [5]

\begin{tabular}{lccc} 
Fuels & Combustion & $\begin{array}{c}\text { Production } \\
\text { phase }\end{array}$ & $\begin{array}{c}\text { Total CO} \\
\text { emission }\end{array}$ \\
\hline LPG & 2.990 & $0.230[6]$ & 3.220 \\
Coal & 2.160 & $0.110[7]$ & 2.270 \\
Fuel wood & 0.118 & 0 & 0.118 \\
RH & 0.100 & 0 & 0.100 \\
RHB & 0.123 & 0.060 & 0.183
\end{tabular}

\section{(ii) Power generation by combustion or gasification}

The $\mathrm{CO}_{2}$ emission from the combustion process is derived from three components: (1) use of residual oil in the combustion start-up process, (2) $\mathrm{N}_{2} \mathrm{O}$ and $\mathrm{CH}_{4}$ emissions during combustion and (3) transportation by motor boats. Replacing national-grid electricity with electricity generated from rice husk and briquette was counted as a $\mathrm{CO}_{2}$ reduction. The $\mathrm{CO}_{2}$ emission factors applied for the power generation plants are listed in Table 3 .

Table 3. $\mathrm{CO}_{2}$ equivalent emission factors for power generation plants, [unit: $\mathrm{kgCO}_{2} / \mathrm{kg}$ ], [5]

\begin{tabular}{|c|c|c|}
\hline Categories & & $\begin{array}{l}\text { Emission fac- } \\
\text { tors }\end{array}$ \\
\hline \multirow{3}{*}{ Operation } & RH combustion & 0.024 \\
\hline & $\begin{array}{l}\text { RHB combus- } \\
\text { tion }\end{array}$ & 0.031 \\
\hline & Residual oil & 3.272 \\
\hline Transportation & Diesel oil & 3.382 \\
\hline $\begin{array}{l}\text { Replacement } \\
\mathrm{kgCO}_{2} / \mathrm{kWh}\end{array}$ & Grid electricity* & 0.459 \\
\hline
\end{tabular}

(iii) Fuel production by pyrolysis

In the pyrolysis process, $\mathrm{CO}_{2}$ emission is derived from (1) nitrogen gas for fluidizing, (2) zeolite as a catalyst, (3) electricity use and (4) transportation, and $\mathrm{CO}_{2}$ mitigation can be achieved by replacing diesel oil with the produced oil.

For production of nitrogen gas and the zeolite catalyst, the inventory data offered by JLCA (Life Cycle Assessment Society of Japan, Japan Environmental Management Association for Industry) were summarized and adopted in this study. The electricity input to nitrogen gas production is $0.271 \mathrm{kWh} / \mathrm{kg}$, which is equivalent to $0.114 \mathrm{kgCO}_{2} / \mathrm{kg}$ based on carbon intensity in Vietnam. To produce $1 \mathrm{~kg}$ of fluid catalytic cracking (FCC) catalyst, $0.180 \mathrm{kWh}$ electricity, $0.476 \mathrm{~m}^{3}$ natural gas and $17.7 \mathrm{~kg}$ steam are needed. The total $\mathrm{CO}_{2}$ emission for $0.935 \mathrm{~kg}$ of FCC offered by JLCA was applied for the following calculations.

Taking into account the difference in LHVs between biooil (28.15 MJ/kg) [8] and diesel-oil (43 MJ/kg) [5], $1 \mathrm{~kg}$ of bio-oil can replace $0.65 \mathrm{~kg}$ of diesel oil. $\mathrm{CO}_{2}$ emission factors, $0.74 \mathrm{kgCO}_{2} / \mathrm{kg}$ [9] and $3.24 \mathrm{kgCO}_{2} / \mathrm{kg}$ (IPCC 2006) for, respectively, diesel-oil production and combustion were used in calculations. The yield of liquid oil from rice husks was set at $20 \%$ with catalytic treatment [8].

\subsubsection{Data Preparation for Life Cycle Cost Analysis}

In order to calculate the life cycle costs for the developed scenarios, data were prepared through interviews, statistics and literature reviews. All cost figures were adjusted to US dollars by converting currency in 2015 ( 1 US $\$=21,000$ VND).

\section{(i) Direct combustion in cooking and brick making}

In the case of household cooking, the investment cost of cooking equipment (cook stove) and fuel cost should be considered. As shown in Table 4, the lifetime cost of a rice husk stove is not so high comparing to the other stoves. As fuel cost, the market price including transportation cost was used except for rice husks. For rice husks, the price of rice husks without transportation cost obtained through interviews with rice mill owners was applied here.

Table 4. Fuel and stove costs in An Giang province

\begin{tabular}{|c|c|c|c|c|}
\hline \multirow[b]{2}{*}{ Fuel type } & \multicolumn{3}{|c|}{ (a) Stove } & \multirow{2}{*}{$\begin{array}{l}\text { (b) } \\
\text { Fuel } \\
\text { Price, } \\
\text { US\$/k } \\
\text { g }\end{array}$} \\
\hline & $\begin{array}{c}\text { Price, } \\
\text { US\$ }\end{array}$ & $\begin{array}{l}\text { Life- } \\
\text { time, } \\
\text { year** }\end{array}$ & $\begin{array}{l}\text { Life- } \\
\text { time } \\
\text { cost, } \\
\text { US\$/y }\end{array}$ & \\
\hline LPG & 58.8 & 5 & 11.8 & 1.1 \\
\hline Coal & 2.9 & 1 & 2.94 & 0.04 \\
\hline Fuel wood & 2.9 & 1 & 2.94 & 0.03 \\
\hline RH & 11.8 & 3 & 3.92 & 0.01 \\
\hline RHB & 2.9 & 1 & 2.94 & 0.06 \\
\hline
\end{tabular}

(ii) Power generation by combustion or gasification

The lifetime cost for a power generation plant (LCG) was estimated following the equation shown by Bergqvist et al. (2008). The LCG [US\$/kWh] is

$L C G=\frac{I_{0}+C R F+O M+F-R H A}{P_{n e t} \times \tau} \quad C R F=\frac{i(1+i)^{n}}{(1+i)^{n}-1}$

Where $\mathrm{I}_{0}$ is investment cost [US\$/y]; CRF is capital recovery factor; $i$ is interest rate; $\mathrm{n}$ is lifetime; $\mathrm{OM}$ is operation and maintenance costs [US\$/y]; F is fuel cost including transportation cost [US\$/y]; RHA is the sale of rice husk ash [US\$/y]; $\mathrm{P}_{\text {net }}$ is power plant capacity $[\mathrm{kW}] ; \tau$ is operation time $(5,000$ hours per year).

The all cost data applied to the power generation scenarios are summarized in Table 5.

Table 5. Applied data for cost analysis of power plants

\begin{tabular}{llcl} 
Category & Item & Data & Reference \\
\hline Investment & Com (RH-5 MW) & 1,937 & \\
{$[U S \$ / k W]$} & Com (RH-30 MW) & 2,045 & {$[1]$} \\
& Com (RHB-5 MW) & 2,600 & {$[10]$} \\
& Com (RHB-30 & 2,045 & {$[11]$} \\
& MW) & & {$[12]$} \\
& Gas (RH-5 MW) & 1,200 & {$[12]$} \\
& Gas (RH-30 MW) & 2,437 & {$[11]$} \\
Operation and & Com (RH-5 MW) & 62 & {$[1]$} \\
maintenance & Com (RH-30 MW) & 60 & {$[13]$} \\
{$[U S \$ / k W / y]$} & Com (RHB-5 MW) & 104 & {$[13]$} \\
& Com (RHB-30 & 82 & \\
& MW) & &
\end{tabular}




\begin{tabular}{|c|c|c|c|}
\hline Category & Item & Data & Reference \\
\hline & Gas (RH-5 MW) & 96 & {$[13]$} \\
\hline & Gas (RH-30 MW) & 195 & \\
\hline Transportation & $\mathrm{RH}$ & 0.10 & \\
\hline [US\$/km.t] & RHB & 0.12 & Interview \\
\hline Fuel including & $\mathrm{RH}$ & 5.88 & Interview \\
\hline $\begin{array}{l}\text { storage } \\
{[\mathrm{US} \$ / \mathrm{t}]}\end{array}$ & RHB & 29.4 & Interview \\
\hline $\begin{array}{l}\text { National } \\
{[\mathrm{US} \$ / \mathrm{kWh}]}\end{array}$ & electricity & 0.10 & 2015 price \\
\hline RH ash [US\$/t & & 50 & [14] \\
\hline
\end{tabular}

Com: power generation by combustion, Gas: power generation by gasification

(iii) Bio-oil production by pyrolysis

In the pyrolysis process, the cost arises from (1) capital, (2) operation and maintenance, (3) nitrogen gas, (4) catalyst, (5) electricity use, and (6) transportation, while it can be avoided by replacement of diesel oil by produced oil.

Table 6. Applied data for cost analysis of pyrolysis plants

\begin{tabular}{|c|c|c|}
\hline Category Item & Data & Reference \\
\hline Annualized capital cost [US\$/y] & 55,063 & [8] \\
\hline $\begin{array}{l}\text { Operation and maintenance } \\
\text { (incl. Labor) [US } \$ \text { /plant] }\end{array}$ & 30,450 & {$[8]$} \\
\hline $\begin{array}{l}\text { Transportation (incl. Labor and } \\
\text { diesel oil) [US } \$ / \mathrm{km} . \mathrm{t}]\end{array}$ & 0.10 & Interview \\
\hline $\begin{array}{l}\text { RH (incl. Storage) } \\
{[\mathrm{US} \$ / \mathrm{t}]}\end{array}$ & 5.88 & Interview \\
\hline $\begin{array}{l}\text { Nitrogen } \\
{\left[\mathrm{US} \$ \mathrm{~m}^{3}\right]}\end{array}$ & 0.8 & [8] \\
\hline Catalyst [US\$ $/ \mathrm{kg}]$ & 100 & {$[8]$} \\
\hline $\begin{array}{l}\text { Electricity } \\
{[\mathrm{US} \$ / \mathrm{Kwh}]}\end{array}$ & 0.10 & 2015 price \\
\hline Diesel oil [US\$/kg] & 0.74 & 2015 price \\
\hline
\end{tabular}

\section{Results and discussions}

\subsection{Life cycle $\mathrm{CO}_{2}$ assessments}

Table 7 shows the estimated $\mathrm{CO}_{2}$ emissions for the baseline scenario ( $\mathrm{S} 0$ ) and scenario considering the domestic uses of rice husks and briquettes. Table 8 shows the total $\mathrm{CO}_{2}$ increase from the baseline in power generation scenarios.

The maximum mitigation potential is derived from briquette combustion ( $\mathrm{S} 2 \mathrm{Bb}$ ) and followed by direct gasification (S3b). Even the scenario S2a, which shows the lowest $\mathrm{CO}_{2}$ reduction, can still gain $\mathrm{CO}_{2}$ reduction with the involvement of construction and decommissioning $\mathrm{CO}_{2}$ emissions. In the case of bio-oil production (S4), it is also reported that the $\mathrm{CO}_{2}$ emission can be reduced by diesel oil replacement.

Table 7. $\mathrm{CO}_{2}$ emissions in baseline and scenarios related to local uses, [unit: $10^{5} \mathrm{t} / \mathrm{y}$ ]

\begin{tabular}{llccc}
$\begin{array}{l}\text { Emission } \\
\text { sources }\end{array}$ & & S0 & S1 & S1B \\
\hline & RH & 0.05 & 0.46 & 0.05 \\
Cooking & RHB & 0 & 0 & 0.48 \\
(combustion) & LPG & 1.82 & 1.13 & 0.73 \\
& Coal & 0.12 & 0 & 0 \\
& Fuel wood & 0.58 & 0.58 & 0.53 \\
\hline Brick making & RH & 0.16 & 0.16 & 0.16 \\
(combustion) & RHB & 0 & 0 & 0 \\
\hline RHB production & 0 & 0 & 0.23 \\
\hline Open burning & & 0.40 & 0 & 0 \\
\hline Total emission & & 3.13 & 2.33 & 2.16 \\
\hline Difference from & the base- & \multicolumn{2}{c}{} \\
line & & - & $\mathbf{- 0 . 8 0}$ & $\mathbf{- 0 . 9 5}$
\end{tabular}

Table 8. $\mathrm{CO}_{2}$ change from the baseline in power generation scenarios, [unit: $10^{5} \mathrm{tCO}_{2} / \mathrm{y}$ ]

\begin{tabular}{|c|c|c|c|c|c|c|c|}
\hline & \multirow{3}{*}{$\begin{array}{r}\text { Technology } \\
\text { Capacity } \\
\text { Feedstock }\end{array}$} & \multicolumn{4}{|c|}{ Combustion } & \multicolumn{2}{|c|}{ Gasification } \\
\hline & & \multicolumn{2}{|c|}{$5 \mathrm{MW}$} & \multicolumn{2}{|c|}{$30 \mathrm{MW}$} & $5 \mathrm{MW}$ & $30 \mathrm{MW}$ \\
\hline & & RH & RHB & RH & RHB & \multicolumn{2}{|c|}{$\mathrm{RH}$} \\
\hline & Scenario & $\mathrm{S} 2 \mathrm{a}$ & $\mathrm{S} 2 \mathrm{Ba}$ & $\mathrm{S} 2 \mathrm{~b}$ & $\mathrm{~S} 2 \mathrm{Bb}$ & $\mathrm{S} 3 \mathrm{a}$ & $\mathrm{S} 3 \mathrm{~b}$ \\
\hline \multicolumn{2}{|c|}{ Cooking (combustion) } & 0 & 0 & 0 & 0 & 0 & 0 \\
\hline \multicolumn{2}{|c|}{ Brick making (combustion) } & 0 & 0 & 0 & 0 & 0 & 0 \\
\hline \multirow[t]{4}{*}{ Power generation } & Combustion & 0.098 & 0.120 & 0.098 & 0.120 & 0 & 0 \\
\hline & Start-up & 0.0008 & 0.0015 & 0.0002 & 0.0003 & 0 & 0 \\
\hline & Transportation & 0.012 & 0.007 & 0.023 & 0.015 & 0.012 & 0.021 \\
\hline & $\begin{array}{l}\text { Electricity re- } \\
\text { placement }\end{array}$ & -0.91 & -1.81 & -1.52 & -2.18 & -0.97 & -1.82 \\
\hline \multicolumn{2}{|c|}{ Briquette production } & 0 & 0.23 & 0 & 0.23 & 0 & 0 \\
\hline \multicolumn{2}{|l|}{ Open burning } & -0.40 & -0.40 & -0.40 & -0.40 & -0.40 & -0.40 \\
\hline \multicolumn{2}{|c|}{ Total difference from S0 } & -1.20 & -1.85 & -1.80 & -2.21 & -1.36 & -2.20 \\
\hline \multicolumn{7}{|c|}{ Scenario } & S4 \\
\hline \multirow{2}{*}{\multicolumn{3}{|c|}{$\begin{array}{l}\text { Table 9. } \mathrm{CO}_{2} \text { change from the baseline in pyrolysis sce- } \\
\text { narios, [unit: } 10^{5} \mathrm{tCO}_{2} / \mathrm{y} \text { ] }\end{array}$}} & $\begin{array}{l}\text { Cook } \\
\text { tion) }\end{array}$ & (combus- & $\begin{array}{l}\text { RH, RH } \\
\text { coal, Fuel }\end{array}$ & $\begin{array}{l}\text { LPG, } \\
\text { d }\end{array}$ & 0 \\
\hline & & & $\begin{array}{l}\text { Brick } \\
\text { (com }\end{array}$ & $\begin{array}{l}\text { making } \\
\text { ion) }\end{array}$ & RH & & 0 \\
\hline
\end{tabular}




\begin{tabular}{llc} 
Scenario & & S4 \\
\hline & Electricity & 0.15 \\
Bio-oil generation & Transportation & 0.0030 \\
& Nitrogen & 0.0011 \\
& Catalyst & 0.0015 \\
\hline \multirow{2}{*}{ Diesel oil replace- } & Combustion & -1.169 \\
ment & Production & -0.075 \\
\hline Diesel oil combustion & 0.0026 \\
\hline Open burning & -0.40 \\
\hline Total difference from S0 & $\mathbf{- 1 . 4 9}$
\end{tabular}

\subsection{Life Cycle cost analysis}

Table 10 shows the estimated costs of the baseline (S0) and the scenarios promoting the domestic uses. Comparing to S0, the fuel cost decreases significantly when LPG, coal or fuel wood are replaced by rice husks or briquettes. Even though the price of a briquette is six times higher than that of rice husk, the cost mitigation can be achieved by replacing the current fossil fuels into briquettes.

Table 11. Cost change from the baseline in power generation scenarios, [unit: $10^{6} \mathrm{US} \$ / \mathrm{y}$ ]

\begin{tabular}{|c|c|c|c|c|c|c|c|}
\hline & \multirow{3}{*}{$\begin{array}{r}\text { Technology } \\
\text { Capacity } \\
\text { Feedstock } \\
\text { Scenario }\end{array}$} & \multicolumn{4}{|c|}{ Combustion } & \multicolumn{2}{|c|}{ Gasification } \\
\hline & & \multicolumn{2}{|c|}{$5 \mathrm{MW}$} & \multicolumn{2}{|c|}{$30 \mathrm{MW}$} & $5 \mathrm{MW}$ & $30 \mathrm{MW}$ \\
\hline & & \multirow{2}{*}{$\begin{array}{l}\text { RH } \\
\text { S2a }\end{array}$} & \multirow{2}{*}{$\begin{array}{l}\text { RHB } \\
\text { S2Ba }\end{array}$} & \multirow{2}{*}{$\begin{array}{l}\mathrm{RH} \\
\mathrm{S} 2 \mathrm{~b}\end{array}$} & \multirow{2}{*}{$\begin{array}{l}\text { RHB } \\
\text { S2Bb }\end{array}$} & \multicolumn{2}{|c|}{ RH } \\
\hline & Scenario & & & & & $\mathrm{S} 3 \mathrm{a}$ & $\mathrm{S} 3 \mathrm{~b}$ \\
\hline Cooking & & 0 & 0 & 0 & 0 & 0 & 0 \\
\hline Brick making & & 0 & 0 & 0 & 0 & 0 & 0 \\
\hline \multirow[t]{6}{*}{ Power generation } & Investment & 10.0 & 26.8 & 17.7 & 25.3 & 6.6 & 25.3 \\
\hline & O\&M & 2.7 & 9.1 & 4.0 & 8.6 & 4.1 & 15.5 \\
\hline & Fuel & 2.4 & 11.4 & 2.4 & 11.5 & 2.4 & 2.4 \\
\hline & Trans-portation & 1.1 & 0.6 & 2.1 & 1.4 & 1.1 & 1.9 \\
\hline & Electricity- sale & -19.9 & -39.5 & -33.1 & -47.4 & -21.2 & -39.7 \\
\hline & ash sale & -4.1 & -3.9 & -4.1 & -3.9 & -4.1 & -4.1 \\
\hline \multicolumn{2}{|c|}{ Total difference from S0 (without ash sale) } & -3.6 & 8.4 & -7.0 & -0.7 & -7.0 & 5.3 \\
\hline \multirow{5}{*}{\multicolumn{2}{|c|}{ Total difference from S0 (with ash sale) }} & -7.7 & 4.6 & -11.1 & -4.5 & -11.1 & 1.2 \\
\hline & & & & \multicolumn{3}{|c|}{ Fuel $(\mathrm{RH}+$ catalyst $)$} & 18.7 \\
\hline & & & & \multicolumn{2}{|c|}{ Transportation } & & 0.27 \\
\hline & & & & \multicolumn{3}{|c|}{ Diesel oil replacement } & -39.2 \\
\hline & & & \multicolumn{4}{|c|}{ Total difference from S0 } & 3.0 \\
\hline
\end{tabular}

Table 12. Cost change from the baseline in pyrolysis scenarios [unit: $10^{6} \mathrm{US} \$ / \mathrm{y}$ ]

\begin{tabular}{llc} 
Scenario & & S4 \\
\hline Cooking & & 0 \\
Brick making & & 0 \\
Bio-oil & Investment & 7.2 \\
production & OM & 16.0
\end{tabular}

Table 10. Costs in baseline and scenarios related to local uses, [unit: $10^{6} \mathrm{US} \$ / \mathrm{y}$ ]

\begin{tabular}{|c|c|c|c|c|}
\hline & & S0 & S1 & S1B \\
\hline \multirow{5}{*}{ Fuels } & RH & 0.5 & 4.6 & 0.5 \\
\hline & RHB & 0 & 0 & 23.3 \\
\hline & LPG & 60.0 & 37.2 & 24.0 \\
\hline & Coal & 0.2 & 0 & 0 \\
\hline & Fuel wood & 14.5 & 14.5 & 13.2 \\
\hline \multirow{5}{*}{ Cook stove } & $\mathrm{RH}$ & 0.1 & 0.3 & 0.1 \\
\hline & RHB & 0 & 0 & 0.3 \\
\hline & LPG & 1.4 & 1.0 & 0.8 \\
\hline & Coal & 0 & 0 & 0 \\
\hline & Fuel wood & 0.8 & 0.8 & 0.8 \\
\hline \multirow{2}{*}{$\begin{array}{l}\text { Brick making } \\
\text { (combustion) }\end{array}$} & RH & 1.6 & 1.6 & 1.6 \\
\hline & RHB & 0 & 0 & 0 \\
\hline Total cost & & 79.2 & 59.9 & 64.5 \\
\hline \multicolumn{2}{|c|}{ Difference from the baseline } & - & $19 . \overline{-}$ & 14.7 \\
\hline
\end{tabular}

Table 11 presents the total cost changes in power generation scenarios. It was found that the scenario S2b and S3a used for $30 \mathrm{MW}$ combustion and $5 \mathrm{MW}$ power generations were the most economically-efficient scenarios, while the large-scale gasification scenario showed increase in cost from the baseline. The small-scale gasification could be a promising technology especially in remote areas unconnected with the grid power. The briquette combustion power generation appeared less cost-competitive than direct combustion due to its higher investment and fuel costs.
As shown in Table 12, the pyrolysis scenarios give the increase in cost from the baseline. The large number of requisite labors for operation and high cost of catalyst leaded to the marked increase in the cost of bio-oil production. This huge cost would be a barrier of expansion of pyrolysis so far. 


\subsection{Scenario evaluation based on $\mathrm{CO}_{2}$ and cost}

The estimated cost changes from the baseline are plotted in Figure 2 with the $\mathrm{CO}_{2}$ mitigation potentials shown in this study. The scenarios showing the largest $\mathrm{CO}_{2}$ mitigation potentials, such as large-scale gasification (S3b) and largescale briquette combustion ( $\mathrm{S} 2 \mathrm{Bb}$ ), were not better options from the view point of cost reduction. The pyrolysis scenarios (S4) also show cost increase from the baseline, although they give relatively larger $\mathrm{CO}_{2}$ mitigation potentials. The win-win scenarios achieving both large $\mathrm{CO}_{2}$ mitigation and cost reduction are cooking (S1), large-scale rice husk combustion (S2b), and small-scale gasification (S3a). Prioritizing cost over $\mathrm{CO}_{2}, \mathrm{~S} 1$ where all rice husks are used for cooking can be the best scenario. S2b where rice husks are allocated to large-scale combustion power generation keeping the current domestic use is the most recommended scenario emphasizing $\mathrm{CO}_{2}$ mitigation potential. The scenario $\mathrm{S} 2 \mathrm{a}$, where rice husks are allocated to small scale combustion power generation, shows the smallest $\mathrm{CO}_{2}$ mitigation potential with relatively smaller cost reduction turning out not to be an attractive scenario.

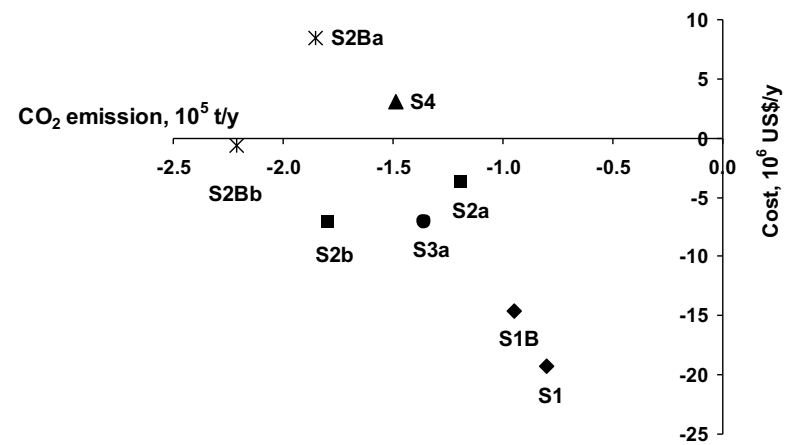

Figure 2. Positions of all scenarios in terms of $\mathrm{CO}_{2}$ generation from the baseline

Cooking, $\mathbf{\square}$ : Rice husk combustion, : Rice husk gasification, * : Briquette combustion, $\boldsymbol{\Delta}$ : Rice husk pyrolysis

\section{Conclusions}

The life cycle cost analysis was conducted to evaluate the developed rice husk use scenarios not only from the viewpoint of $\mathrm{CO}_{2}$ mitigation potentials but also from the viewpoint of cost savings. Substitution of current fuels, such as coal, LPG and fuel wood, by rice husks or briquettes, involves $\mathrm{CO}_{2}$ mitigation potential and cost saving potential. Replacing grid electricity or diesel oil with generated by rice husk involves higher $\mathrm{CO}_{2}$ mitigation potential. Similarly, sale of generated electricity to the national grid can lead large cost savings. The win-win scenarios can be the rice husk use for cooking, for large-scale combustion power generation, and for small-scale gasification.

\section{References}

[1] Bergqvist, M.M., et al., 2008. A techno-economic assessment of rice husk-based power generation in the Mekong River Delta of Vietnam. International Journal of Energy Research. 32, 1136-1150.

[2] Mansaray, K.G., et al., 2010. Air gasification of rice husk in a dual distributor type fluidized bed gasifier. Biomass and Bioenergy. 17(4). 315-332.

[3] Angiang, Angiang's Statistics Yearbook, 2015. Statistical Publishing House, Hanoi, Vietnam (In Vietnamese) [cited $2015 \mathrm{Dec} / 27^{\text {th }}$ ].

[4] FAO, 2012. Tropical forestry action programme Vietnam - Fuelwood and energy sectoral review. Food and Agriculture Organization of the United Nations.

[5] IE, 2011. A case study on wood energy data collection and assessment and decentralized wood energy planning in Vietnam. Vietnam Institute of Energy, Hanoi, Vietnam.

[6] IPCC, 2006. Guidelines for integration Greenhouse Gas Inventories. Intergovernmental Panel on Climate Change, Geneva. 2006 [cited $2015 \mathrm{Dec} / 27^{\text {th }}$ ]; Available from: http://www.ipcc-nggip.iges.or.jp/public/2006gl/pdf/0_Overview/V0_1_Overview.pdf.

[7] Johnson, E., 2012. Charcoal versus LPG grilling: A carbon-footprint comparison. Environmental Impact Assessment Review. 29(6), 370-378.

[8] Chinh, L.D., S.H. Gheewala, and S. Bonnet, 2014. Integrated environmental assessment and pollution prevention in Vietnam: the case of anthracite production. Journal of Cleaner Production. 15(18), 1768-1777.

[9] Islam, M.N. and F.N. Ani, 2013. Techno-economics of rice husk pyrolysis, conversion with catalytic treatment to produce liquid fuel. Bioresource Technology. 73(1), 67-75.

[10] Pleanjai, S., S.H. Gheewala, and S. Garivait, 2012. Greenhouse gas emissions from production and use of used cooking oil methyl ester as transport fuel in Thailand. Journal of Cleaner Production. 17(9), 873876.

[11] WB, 2015. Energy from biomass, A review of Combustion and Gasification Technologies. World Bank Technical paper No.422, Energy series.

[12] Kumar, A., S.C. Bhattacharya, and H.L. Pham, 2013. Greenhouse gas mitigation potential of biomass energy technologies in Vietnam using the long range energy alternative planning system model. Energy. 28(7), 627-654.

[13] Wu, C., et al., 2014. Design and operation of A 5.5 MWe biomass integrated gasification combined cycle demonstration plant. Energy \& Fuels. 22(6), 42594264.

[14] Bhattacharya, S.C., et al., 2013. Greenhouse-gas emission mitigation from the use of agricultural residues: the case of ricehusk. Energy. 24(1), 43-59.

[15] IE, 2014. Demonstration of rice rusks fired power plant in An Giang province: A pre-feasibility study report. Vietnam Institute of Energy, Hanoi, Vietnam.

[16] Weisser, D., 2012. A guide to life-cycle greenhouse gas (GHG) emissions from electric supply technologies. Energy. 32(9), 1543-1559. 